\author{
ks. Tomasz Pawlak
}

Ius Matrimoniale

Sąd Biskupi Siedlecki

\title{
Badanie przedprocesowe czyli duszpasterskie, w świetle motu proprio „Mitis Iudex Dominus Iesus”
}

\section{Wstęp}

Promulgacja motu proprio „Mitis Iudex Dominus Iesus” spowodowała wiele dyskusji na temat procedury orzekania nieważności małżeństwa zarówno na płaszczyźnie publicystycznej jak też w gronie kanonistów. Według niektórych publicystów wydanie dokumentu ma ułatwić osobom rozwiedzionym wejście w nowy związek sakramentalny. Taki sposób rozumowania jest jednak sprzeczny z logiką tego dokumentu. Należy zauważyć, że jedną z podstawowych zasad tego motu proprio jest ochrona nierozerwalności małżeństwa ${ }^{1}$. Papież Franciszek do tej zasady odwołał się w motu proprio aż czterokrotnie ${ }^{2}$. Dokument ten zawiera przepisy, które wprowadzają innowację w procedurze stwierdzania nieważności małżeństwa. Istotnym novum jest stworzenie instytucji badania przedprocesowego dla osób doświadczonych rozpadem małżeństwa sakramentalnego. Jednym z celów tego badania jest określenie sytuacji kanonicznej tych osób i możliwo-

\footnotetext{
1 Por. Franciszek, List apostolski motu proprio „Mitis Iudex Dominus Iesus”, reformujacy kanony Kodeksu Prawa Kanonicznego dotyczace spraw o orzeczenie nieważności małżeństwa. Wstęp, AAS 107 (2015), s. 958.

2 Por. W. Góralski, Wprowadzenie do motu proprio „Mitis Iudex Dominus Iesus”, w: J. KRAJCZyński (red.), Proces małżeński według motu proprio „Mitis Iudex Dominus Iesus", Płock 2015, s. 16.
} 
ści rozpoczęcia procesu o stwierdzenie nieważności małżeństwa. To badanie przedprocesowe jest nazywane duszpasterskim, co wskazuje, że nie można go sprowadzić wyłącznie do porady prawno-kanonicznej. Nie sposób pominąć tego, że Ojcowie Synodalni w 2015 r. wezwali do otoczenia opieką duszpasterską osób doświadczonych rozpadem małżeństwa w następujących słowach: „Szczególnie pilna wydaje się posługa wobec tych osób, których małżeństwo się rozpadło. Dramat separacji często przychodzi na zakończenie długich lat konfliktu i powoduje najwięcej cierpień u dzieci. Samotność małżonka opuszczonego, lub który został zmuszony przerwać współżycie nacechowane nieustannym i poważnym znęcaniem się wymaga szczególnej opieki ze strony wspólnoty chrześcijańskiej”3. Właściwie przeprowadzone badanie przedprocesowe może być jedną z form pomocy osobom doświadczonym dramatem rozbicia małżeństwa sakramentalnego. L. Adamowicz pokreślił, że badanie przedprocesowe to „zwyczajna praca duszpasterska, a nie działania o charakterze dodatkowym, uzupełniającym i nadzwyczajnym" .

\section{Obowiązki biskupa diecezjalnego względem osób doświadczonych rozpadem małżeństwa sakramentalnego}

Papież Franciszek w motu proprio „Mitis Iudex Dominus Iesus” podkreślił, że obowiązek troski o osoby, których związek sakramentalny się rozpadł wynikają z postanowień kan. $383 \$ 1 \mathrm{KPK}^{5}$. Z treści

\footnotetext{
3 Xiv Zwyczajne Zgromadzenie Ogólne Synodu Biskupów, Misja i powołanie rodziny $w$ Kościele $i$ wświecie współczesnym, p. 78, AAS 107 (2015), s. 1161-1221.

4 L. AdAmowicz, Okoliczności osób i rzeczy zezwalające na prowadzenie procesu skróconego, w: J. KRAJCZYŃsKi (red.), Proces małżeński według motu proprio, dz. cyt., s. 95

${ }^{5}$ Kan. 383 KPK $\$ 1$ : „Wypełniając swoja pasterską posługę, biskup diecezjalny winien się troszczyć o wszystkich wiernych powierzonych jego pieczy, bez względu na ich wiek, pozycję czy narodowość, zarówno o stałych mieszkańców, jaki o tych, którzy czasowo przebywają na jego terytorium, okazując apostolską troskę także wobec tych, którzy z racji warunków życia nie mogą wystarczająco korzystać ze zwyczajnej formy pasterzowania oraz wobec niepraktykujących".
} 
cytowanego kanonu wynika, że biskup diecezjalny powinien swoją pieczą pasterską otaczać wszystkie osoby znajdujące się na terytorium jego diecezji. W świetle przepisu kan. $383 \$ 1$ biskup diecezjalny nie może dyskryminować niektórych osób lub grup osób, wśród których prawodawca w sposób literalny wymienił takie kategorie jak wiek, pozycja czy narodowość. Należy zauważyć, że ten katalog nie ma charakteru zamkniętego, a zatem biskup diecezjalny nie może obowiązkiem posługi pasterskiej pomijać innych grup osób.

Prawodawca kościelny podkreślił, że biskup diecezjalny troską pasterską powinien otoczyć tych, którzy z racji warunków swego życia nie mogą wystarczająco korzystać ze zwyczajnej formy pasterzowania oraz niepraktykujących. Właśnie osoby doświadczone rozpadem małżeństwa sakramentalnego można zakwalifikować do jednej z wyżej wymienionych grup osób. Zaniedbania w praktykach religijnych tych osób są uwarunkowane licznymi przyczynami. W niektórych przypadkach osoby po rozpadzie małżeństwa sakramentalnego czują się w sposób subiektywny przez Kościół odrzucone i napiętnowane. $\mathrm{Z}$ tego względu porzucają one praktyki religijne. Papież Franciszek w adhortacji „Amoris laetitia” zachęcał, „aby osoby rozwiedzione, żyjące w nowych związkach odczuwały, że są częścią Kościoła, że «nie są ekskomunikowane» i nie są traktowane jako takie, bo zawsze tworzą wspólnotę kościelną. Sytuacje te wymagają uważnego rozeznania i towarzyszenia im z wielkim szacunkiem, unikając wszelkiego języka i postawy, które dałyby im odczuć, że są dyskryminowani, oraz popierania ich udziału w życiu wspólnoty. «Troska o te osoby nie jest dla wspólnoty chrześcijańskiej osłabieniem jej wiary i jej świadectwa o nierozerwalności małżeńskiej, ale raczej w trosce tej wyraża ona swą miłość»" ". Wezwanie papieża powinno mobilizować duszpasterzy do tego, aby osoby doświadczające rozbicia małżeństwa mogły odnaleźć swoje miejsce we wspólnocie Kościoła. Biskup diecezjalny powinien zaproponować takie rozwiązania, aby ten postulat był realizowany w praktyce.

6 Franciszek, Posynodalna adhortacja apostolska „Amoris laetitia”, p. 243, AAS 108 (2016), s. 311-446. 
Należy także opieką duszpasterską otoczyć również osoby wrażliwe religijnie, ponieważ one często uważają, że są winne zerwaniu więzi małżeńskiej i nie czują się godnymi do tego, aby uczestniczyć w praktykach religijnych. Inne osoby uczestniczą w praktykach religijnych, ale niektórzy ze względu na wejście w kolejny związek nie mogą przystępować do sakramentu Komunii Świętej. Takie osoby zwykle chcą uregulować swoją sytuację kanoniczną i chcą prosić Kościół o zbadanie ważności ich nieudanego małżeństwa sakramentalnego.

Zgodnie $\mathrm{z}$ art. 1 „Zasad proceduralnych $\mathrm{w}$ sprawach o stwierdzenie nieważności małżeństwa"7 biskup diecezjalny powinien otoczyć troską małżonków żyjących w separacji oraz rozwiedzionych. Prawodawca w przytoczonym przepisie wprost nie odnosi się wyłącznie do osób, których uległo rozpadowi małżeństwo sakramentalne, aczkolwiek wynika to z kontekstu całego dokumentu. Biorąc jednak pod uwagę, że prawodawca w kan. $383 \$ 4 \mathrm{KPK}$ zobowiązuje biskupa diecezjalnego do objęcia posługą również nieochrzczonych należałoby przepisy tego kanonu rozszerzyć również na niekatolików oraz osoby nieochrzczone. Wynika to z tego, że biskup powinien się zatroszczyć również o te osoby, o ile one zwrócą się do niego z taką prośbą. Może być to sytuacja, gdy osoba ma wątpliwości co do ważności poprzedniego związku małżeńskiego, a chce jako niekatolik przystąpić do pełnej wspólnoty Kościoła lub jako nieochrzczony chce przyjąć chrzest w Kościele katolickim. Biskup w obu przypadkach powinien pomóc ustalić takiej osobie jej sytuację kanoniczną w Kościele. Biskup diecezjalny zwykle nie ma zbyt często bezpośredniego kontaktu $z$ wiernymi i dlatego jego zadanie może się ograniczyć do zorganizowania struktur, wydania odpowiednich przepisów oraz wyznaczenia osób odpowiedzialnych za pomoc takim wiernym, chociaż to nie wyklucza osobistego zaangażowania samego biskupa. Przedstawione inicjatywy mają pomóc osobom doświadczającym rozbicia małżeństwa odnaleźć się w takiej sytuacji.

7 Fr ANCISZEK, Zasady proceduralne w sprawach o stwierdzenie nieważności matżeństwa, art. 1, AAS 107 (2015), s. 967-970. 
Prawodawca zobowiązał ordynariusza miejsca, aby wyznaczył odpowiednie osoby do prowadzenia badania przedprocesowego ${ }^{8}$. Analizując treść art. 3 „Zasad proceduralnych w sprawach o stwierdzenie nieważności małżeństwa” rodzi się pytanie czy też jest to brak konsekwencji prawodawcy skoro art. 1 „Zasad proceduralnych w sprawach o stwierdzenie nieważności małżeństwa" wskazuje wyłącznie na biskupa diecezjalnego. Wydaje się jednak, że jest to zamierzona decyzja legislatora. Wnikliwa analiza pozwala zauważyć, że biskup diecezjalny w tym przypadku jest odpowiedzialny za wszystkie osoby będące w separacji lub rozwiedzione, które kwestionują ważność zawartego małżeństwa, zaś ordynariusz miejsca powinien wziąć odpowiedzialność tylko za organizację struktur odpowiedzialnych za prowadzenie procesu. Zatem prawodawca kościelny nałożył szersze zobowiązania na biskupa diecezjalnego niż na ordynariusza miejsca. Należy podkreślić, że biskup diecezjalny jest zawsze ordynariuszem miejsca. Prawodawca mógł zatem użyć terminu „ordynariusz miejsca” z dwóch powodów. Po pierwsze osoby doświadczone rozpadem związków są nie tylko na obszarach posiadających struktury diecezjalne, ale również są obecne w strukturach kościelnych zrównanych $\mathrm{z}$ diecezją. $\mathrm{W}$ związku $\mathrm{z}$ tym prawodawca użył terminu ordynariusz miejsca, aby podmiotem upoważnionym do desygnowania osób odpowiedzialnych za prowadzenia badania przedprocesowego uczynić również administratora apostolskiego, wikariusza apostolskiego, prefekta apostolskiego, prałata terytorialnego oraz opata terytorialnego ${ }^{9}$. Wikariusz generalny i wikariusz biskupi jest również ordynariuszem miejsca ${ }^{10}$. Można domniemywać, że prawodawca użył terminu ordynariusz miejsca, aby odciążyć biskupa diecezjalnego z tego obowiązku. W związku z tym wikariusz generalny i biskupi może wyznaczyć osoby odpowiedzialne za prowadzenia badanie przedprocesowego. Jest to właśnie drugi powód użycia pojęcia ordynariusz miejsca. Na-

\footnotetext{
${ }^{8}$ Por. Zasady proceduralne $w$ sprawach o stwierdzenie nieważności małżeństwa, art. 3.

9 Por. kan. 370-371 KPK.

10 Por. kan. 134 KPK.
} 
leży jednak podkreślić, że nawet jeśli zadanie desygnowania osób odpowiedzialnych za to dochodzenie zostaje scedowane na wikariusza generalnego lub biskupiego, to troska o właściwe funkcjonowanie struktur spoczywa na biskupie diecezjalnym lub osobie zrównanej w prawie biskupowi diecezjalnemu. W kontekście tych analiz nasuwa się wniosek, że biskup diecezjalny lub zrównany z nim w prawie i stojący na czele kościoła partykularnego mógłby mianować stałego przedstawiciela do spraw prowadzenia badania przedprocesowego, który odpowiadałby za całość organizacji struktur w określonej jednostce administracji kościelnej.

\section{Zadania proboszcza}

Biskup inicjatywy duszpasterskie realizuje przez prezbiterów, a w sposób szczególny dokonuje się to przez współpracę z proboszczami $^{11}$. Biskup diecezjalny jest upoważniony do narzucania swojej woli proboszczowi ${ }^{12}$. Natomiast proboszcz ma obowiązek podejmowania działań zgodnie z linią pracy duszpasterskiej wyznaczoną przez biskupa diecezjalnego ${ }^{13}$. $\mathrm{Z}$ tego względu drugim podmiotem wskazanym przez prawodawcę kościelnego zobowiązanym do pomocy osobom będącym w separacji lub rozwiedzionym jest proboszcz $^{14}$. To zadanie wynika również z postanowienia kan. 529 KPK $\$ 1 \mathrm{KPK}$, którego przepis brzmi: „Pragnąc dobrze wypełnić funkcję pasterza, proboszcz powinien starać się poznać wiernych powierzonych jego pieczy (...). Szczególną troską otacza biednych, cierpiących, samotnych, wygnańców oraz przeżywających szczególne trudności. Stara się wreszcie o to, by małżonkowie i rodzice otrzymali pomoc do wypełniania własnych obowiązków oraz popiera wzrost życia

\footnotetext{
11 Por. kan. $529 \$ 2$ KPK.

12 Por. P. KRосZeK, Zasady proceduralne w sprawach o stwierdzenie nieważności małżeństwa, w: P. Skonieczny (red.), Praktyczny komentarz do Listu apostolskiego motu proprio „Mitis Iudex Dominus Iesus” papieża Franciszka, Tarnów 2015, s. 42. 13 Por. G. Sheeny (red.), The Canon Law, Letter \& Spirit: a Practical Guide to the „Code of Canon Law”, can. 519, n. 1029.

14 Por. kan. $529 \$ 2$ KPK.
} 
chrześcijańskiego w rodzinach (...). Proboszcz jest zobowiązany do tego, aby poznać swoich parafian i sytuację w której oni się znajdują. Prawodawca kościelny zwraca uwagę, że proboszcz powinien być wrażliwy na sytuacje osób przeżywających trudności i życie chrześcijańskie w rodzinach. Osoby, które doświadczyły rozpadu małżeństwa sakramentalnego w sposób szczególny kwalifikują się do tego, aby proboszcz zainteresował się ich losem i pomógł rozeznać ich sytuację kanoniczną. O ile biskup diecezjalny może pomóc osobom żyjącym w separacji i rozwiedzionym głównie przez zorganizowanie struktur pomocy czy też wydanie odpowiednich przepisów, o tyle proboszcz może pomóc $\mathrm{w}$ sposób bezpośredni $\mathrm{z}$ uwzględnieniem określonej sytuacji tych osób.

\section{Rola struktur diecezjalnych i parafialnych}

Przepis art. 1 „Zasad proceduralnych w sprawach o stwierdzenie nieważności małżeństwa" określa sytuacje, które stanowią przedmiot normy. Wśród nich należy wyróżnić wiernych, którzy żyją w separacji ustanowionej prawem kanonicznym oraz tych, których rozwód został orzeczony na forum państwowym ${ }^{15}$. Do osób objętych badaniem przedprocesowym należy zaliczyć także innych wiernych, którzy po rozpadzie małżeństwa są złączeni ślubem cywilnym, żyjącym bez związku formalnego lub też żyją samotnie. Prawodawca kościelny postanowił, aby biskup diecezjalny wraz z proboszczem otoczyli troską duszpasterską osoby doświadczone rozpadem małżeństwa sakramentalnego. Ma temu służyć powołanie specjalnych struktur parafialnych i diecezjalnych ${ }^{16}$. Prawodawca daje zatem biskupowi możliwość wyboru, aby ten określił jaki system będzie lepiej spełniał zadanie pomocy tym osobom. Biorąc pod uwagę art. 1 „Zasad proceduralnych w sprawach o stwierdzenie nieważności małżeństwa” należy stwierdzić, że biskup przed podjęciem decyzji o sposobie powo-

15 Por. P. KRoczen, Zasady proceduralne w sprawach o stwierdzenie nieważności małżństwa, dz. cyt., s. 42.

16 Zasady proceduralne w sprawach o stwierdzenie nieważności małżeństwa, art. 1. 
łania wspomnianych struktur powinien swoją decyzję skonsultować z proboszczami, którzy powinni mieć dobre rozeznanie na temat sytuacji osób przebywających na terenie swoich parafii. To właśnie opinie proboszczów mogą pomóc zdiagnozować czy w każdej parafii jest potrzeba powołania takich struktur, czy też wystarczy, aby one zaistniały tylko na szczeblu diecezjalnym. Chociaż prawodawca nie przewidział takiej sytuacji, to można zaproponować, aby w niektórych sytuacjach powołać strukturę pośrednią pomiędzy parafialną a diecezjalną np. na poziomie dekanatu czy też rejonu duszpasterskiego.

Prawodawca kościelny w art. 2 „Zasad proceduralnych w sprawach o stwierdzenie nieważności małżeństwa” postanowił, aby wspomniane powyżej struktury miały na celu poznanie sytuacji osób będących w separacji lub rozwiedzionych, którzy poddają w wątpliwość ważność swojego małżeństwa lub też są przekonani o jego nieważności. Osoby odpowiedzialne do zapoznania się z sytuacją wiernych powinny wnikliwie i wszechstronnie poznać okoliczności poznania się małżonków, podjęcia przez nich decyzji o zawarciu małżeństwa i sposobie funkcjonowania tego związku. Należy jednak zwrócić uwagę, że nie może być to wyłącznie jednostronne spojrzenie z punktu widzenia osób, które mają wątpliwość co do ważności małżeństwa. Należy bowiem przypomnieć, że w myśl kan. 1060 KPK małżeństwo cieszy się przychylnością prawa ${ }^{17}$. W badaniu spraw osób, których małżeństwo się rozpadło nie wolno zatem pomijać argumentów, które świadczą o jego ważności. Powołane struktury muszą w wykonywaniu swoich zadań również stać na straży trwałości i świętości węzła małżeńskiego.

Prawodawca określił badania przedprocesowe przymiotem „duszpasterskie”. P. Kroczek uważa, że taki zabieg legislacyjny ma odrzucić bezpośrednie skojarzenie tej instytucji prawnej z dochodzeniem wstępnym związanym z procesem karnym ${ }^{18}$. Takie uzasadnienie nie jest jednak do końca przekonujące. Użycie takiego wyrażenia

\footnotetext{
17 Por. kan. 1060 KPK.

18 Por. P. KRoczek, Zasady proceduralne w sprawach o stwierdzenie nieważności małżństwa, dz. cyt., s. 44.
} 
podkreśla istotny wymiar tego postępowania, które powinno mieć charakter duszpasterski.

P. Kroczek stwierdza, że „celem badania przedprocesowego jest uzyskanie informacji, które mogą być pomocne w procesie sądowym o stwierdzenie nieważności małżeństwa, niezależnie od formy tego procesu"19. Wskazany przez autora cel można określić jednak tylko jako główny. Skoro prawodawca w kan. 1675 KPK nakazuje sędziemu przed przyjęciem sprawy uzyskać pewność, że nie ma możliwości wznowienia wspólnoty życia małżeńskiego, to tym bardziej takie zadanie musi wypełnić prowadzący badanie przedprocesowe. Ponadto gdyby w badaniu duszpasterskim chodziło tylko o znalezienie podstaw nieważności małżeństwa, to prawodawca nie sytuowałby go $\mathrm{w}$ ramach diecezjalnego duszpasterstwa małżeńst $\mathrm{w}^{20}$, ale $\mathrm{w}$ ramach specjalistycznych poradni prawnych.

Nie wolno zatem ograniczyć badania przedprocesowego z osobą żyjącą w separacji lub rozwiedzioną do poszukiwania ewentualnych podstaw nieważności małżeństwa. Rozmowa mająca na celu znalezienie przyczyn nieważności małżeństwa może być przeprowadzona w poradni sądowej lub też przez adwokata. Udzielanie pomocy przez poradnię sądową lub przez adwokata było praktykowane przez Kościół przed reformą papieża Franciszka, zaś badanie przedprocesowe jest nową instytucją. Należy zatem wnioskować, że zamiarem prawodawcy nie było zastępowanie dotychczasowych form pomocy sądowej wiernym, ale uzupełnienie jej wymiarem duszpasterskim. Chociaż sądownictwo kościelne stanowi element działalności pasterskiej Kościoła, to trzeba zauważyć, że prawodawca wspominając o wymiarze duszpasterskim badania przedprocesowego nie wykluczał pozasądowych form oddziaływania.

Głównym celem prawa kościelnego jest zbawienie dusz ${ }^{21}$, a badanie przedprocesowe wpisuje się doskonale w jego realizację. Papież

\footnotetext{
19 Por. TAMżE.

20 Zasady proceduralne w sprawach o stwierdzenie nieważności mał̇̇eństwa, art. 2.

21 Por. R. SobAński, Nauki podstawowe prawa kanonicznego. Teologia prawa kanonicznego, Warszawa 2001, s. 115.
} 
Jan Paweł II w przemówieniu do Roty Rzymskiej zwrócił uwagę, że sędzia kościelny to duszpasterz, który powinien pochylać się nad zagubioną i zranioną owcą ${ }^{22}$. Alegorię użytą przez papieża Jana Pawła II względem sędziego kościelnego można odnieść w bardzo szerokim rozumieniu do postawy osoby prowadzącej badanie przedprocesowe. Powinna ona umieć pochylić się i zrozumieć sytuację w której znalazł się wierny. Prowadzący badanie duszpasterskie nie powinien jednak patrzeć na osobę doświadczoną rozbiciem małżeństwa wyłącznie z punktu widzenia sędziego, który ocenia takiego wiernego i jego sytuację, ale powinien być bardziej jak pasterz, który pochyla się nad zranioną owcą.

Wymiar duszpasterski tego badania jest istotny z innego względu. Należy bowiem założyć, że nie w każdym przypadku, gdy osoba zwróci się o pomoc uzyska satysfakcjonujące rozwiązanie. W sytuacji osób doświadczonych rozpadem małżeństwa sakramentalnego nie w każdym przypadku będzie można znaleźć podstawy do zaskarżenia jego nieważności. Wówczas bardzo ważną sprawą jest otoczenie takiej osoby pomocą duszpasterską, do czego wzywał Jan Paweł II w następujący sposób: „(...) Razem z Synodem wzywam gorąco pasterzy i całą wspólnotę wiernych do okazania pomocy rozwiedzionym, do podejmowania z troskliwą miłością starań o to, by nie czuli się oni odłączeni od Kościoła, skoro mogą, owszem, jako ochrzczeni, powinni uczestniczyć w jego życiu. Niech będą zachęcani do słuchania Słowa Bożego, do uczęszczania na Mszę świętą, do wytrwania w modlitwie, do pomnażania dzieł miłości oraz inicjatyw wspólnoty na rzecz sprawiedliwości, do wychowywania dzieci w wierze chrześcijańskiej, do pielęgnowania ducha i czynów pokutnych, ażeby w ten sposób z dnia na dzień wypraszali sobie u Boga łaskę. Niech Kościół modli się za nich, niech im dodaje odwagi, niech okaże się miłosierną matką, podtrzymując ich w wierze i nadziei $(. . .)^{23 "}$.

\footnotetext{
22 Por. Ioannes Paulus II, Allocutio ad Romanae Rotae praelatos auditores, 17.01.1998, AAS 90 (1998), s. 781-782.

23 Por. Jan PAWE⿺ II, Adhortacja apostolska O zadaniach rodziny chrześcijańskiej w świecie współczesnym „Familiaris consortio”, p. 84, AAS 74 (1982), s. 82-191.
} 
Prowadzący powinien przede wszystkim uświadomić osobie doświadczonej rozpadem małżeństwa, że nie jest odrzucona i wykluczona ze wspólnoty Kościoła. Potrzeba w tej sytuacji wzbudzić nadzieję i ukazać sens angażowania w życie Kościoła, gdyż w takich sytuacjach osoby rozluźniają bądź zrywają więzi z tą wspólnotą poprzez zaniedbanie praktyk niedzielnych czy też osobistej modlitwy. Osobom, które nie weszły w kolejny związek należy przypominać, że nie mają zamkniętej drogi do korzystania z sakramentów pokuty i Eucharystii. Czasem bowiem się zdarza, że osoby znajdujące się w takiej sytuacji czując się winnymi rozpadu małżeństwa nie wiedzą o możliwości korzystania z tych sakramentów.

Innym sposobem pomocy może być rozwiązanie zaproponowane w adhortacji apostolskiej „Familiaris consortio” ${ }^{24}$. Papież Jan Paweł II umożliwił w tym dokumencie, aby osoby, które żyją w związku niesakramentalnym mogły korzystać z sakramentów pokuty i Eucharystii pod określonymi warunkami. Przede wszystkim małżonkowie powinni uznać naukę Chrystusa o nierozerwalności małżeństwa mając świadomość tego, że się jej sprzeniewierzyli, ponieważ złamali przymierze sakramentalne i żyją w nowych związkach cywilnych. Ponadto dotyczy to tylko tych małżonków, którzy nie mogą zrezygnować ze związku z drugim partnerem wyłącznie z ważnych powodów, np. ze względu na wychowanie dzieci lub świadczenie sobie wzajemnej opieki. Kolejnym istotnym warunkiem jest zobowiązanie takich osób do życia w pełnej wstrzemięźliwości seksualnej w sposób całkowity, bezwarunkowy i stały. Osobom, które zdecydują się w taki sposób postępować

${ }^{24}$ Jan PaWe€ II, Adhortacja apostolska O zadaniach rodziny chrześcijańskiej w świecie wspótczesnym „Familiaris consortio”, p. 84: „(..) Pojednanie w sakramencie pokuty - które otworzyłoby drogę do komunii eucharystycznej - może być dostępne jedynie dla tych, którzy żałując, że naruszyli znak Przymierza i wierności Chrystusowi, są szczerze gotowi na taką formę życia, która nie stoi w sprzeczności z nierozerwalnością małżeństwa. Oznacza to konkretnie, że gdy mężczyzna i kobieta, którzy dla ważnych powodów - jak na przykład wychowanie dzieci nie mogąc uczynić zadość obowiązkowi rozstania się, „postanawiają żyć w pełnej wstrzemięźliwości, czyli powstrzymywać się od aktów, które przysługują jedynie małżonkom (...)". 
należy przypomnieć, że nie może zachodzić niebezpieczeństwo zgorszenia. Oznacza to w praktyce, że powinni przyjmować sakramenty poza swoja parafią. Osoba prowadząca takie badanie przedprocesowe powinna w tym zakresie udzielić wiernym istotnych informacji.

Ojcowie Synodalni w 2015 r. zwrócili uwagę na to, że osoby doświadczone rozpadem małżeństwa należy formować do postawy przebaczania. „Przebaczenie z powodu doznanej niesprawiedliwości nie jest łatwe, ale jest procesem, jaki umożliwia łaska. Wypływa stąd potrzeba duszpasterstwa nawrócenia i pojednania, także poprzez wyspecjalizowane środki poradnictwa i mediacji, jakie należy ustanowić w diecezjach. Trzeba też promować sprawiedliwość względem wszystkich stron biorących udział w nieudanym małżeństwie (małżonkowie i dzieci). Wspólnota chrześcijańska i jej pasterze mają obowiązek żądać od małżonków, w separacji i rozwiedzionych, aby traktowali siebie nawzajem z szacunkiem i miłosierdziem, zwłaszcza dla dobra dzieci, którym nie powinno się powodować dalszych cierpień." ${ }^{25}$. Treść dokumentu synodalnego wyraźnie wskazuje, że na duszpasterzach ciąży obowiązek prowadzenia osób do pojednania, nawet jeśli nie jest możliwe wznowienie wspólnoty małżeńskiej. Istotną metodą jest formacja duchowa i moralna w której należy podkreślać, że jedną z kluczowych postaw chrześcijanina jest przebaczenie. Ojcowie Synodalni zwrócili jednak uwagę, że oprócz bazowania na łasce Bożej należy w tym celu wykorzystać wyspecjalizowane ośrodki poradnictwa i mediacji. Stanowi to uzupełnienie i dopełnienie formacji do przebaczenia. Z dokumentu Synodu Biskupów z 2015 r. wynika, że motywem prowadzenia osób doświadczonych rozbiciem małżeństwa do przebaczenia nie jest tylko relacja między małżonkami, ale również dobro dzieci. W kontekście troski o dzieci należy przypominać małżonkom o obowiązkach naturalnych stron wobec dzieci dotyczących utrzymania i wychowania. W niektórych sytuacjach, gdy małżonkowie nie potrafią prawidłowo wypełniać zadania rodzica należałoby również skierować do odpowiedniej instytucji,

25 XiV Zwyczajne Zgromadzenie Ogólne Synodu Biskupów, Misja i powołanie rodziny w Kościele $i$ wświecie współczesnym, dz. cyt., p. 79. 
która pomogłaby skorygować dysfunkcje. Takim miejscem może być poradnia rodzinna, gdzie osoba otrzyma fachową pomoc specjalisty. Duszpasterz powinien jedynie naświetlić problem i wskazać źródło rozwiązania. Jest to też zgodne z zasadą pomocniczości, którą wypracował Kościół i wzywa do jej aplikowania ${ }^{26}$. Odpowiadając na wezwanie Ojców Synodalnych prowadzący badanie procesowe powinni również wziąć pod uwage jako cel swojego działania wzbudzenia u małżonka postawy przebaczenia i troski o dobro dzieci.

Prowadzący badanie przedprocesowe w sytuacji, gdy nie zauważa podstaw do zaskarżenia małżeństwa może zaproponować udział w duszpasterstwie związków niesakramentalnych. Uczestnictwo w takiej wspólnocie pomaga dostrzec, że są inni małżonkowie dotknięci podobnym problemem, ale nade wszystko motywuje do większego zaangażowania w Kościele i nadaje nowy sens ich życiu.

Wskazanych powyżej form pomocy i opieki duszpasterskiej osób doświadczonych rozpadem małżeństwa sakramentalnego nie jest w stanie wykonać osoba prowadząca badanie przedprocesowe, ponieważ wymaga to czasu oraz zastosowania odpowiednich środków. Z tego względu prawodawca kościelny postuluje, aby dochodzenie miało miejsce w ramach jednolitego diecezjalnego duszpasterstwa małżeństw ${ }^{27}$. Diecezjalne duszpasterstwo rodzin ma zwykle rozbudowane struktury i kompetentnych specjalistów, aby adekwatnie pomagać osobom z konkretnymi problemami. Oprócz ofert typowo duszpasterskich może służyć doraźnymi formami pomocy takimi jak pomoc psychologa czy terapeuty. W tym kontekście należy się zastanowić czy podczas badania przedprocesowego nie jest stosownym podjęcie próby doprowadzenie małżonków do pojednania i wznowienia wspólnoty życia. Prawodawca kościelny w „Zasadach proceduralnych w sprawach o stwierdzenie nieważności małżeństwa” nie przewidział takiej sytuacji, ale tego nie wykluczał. Wydaje się zatem

\footnotetext{
26 Por. KKK, n. 1883.

27 Por. Zasady proceduralne w sprawach o stwierdzenie nieważności małżeństwa, art. 2.
} 
zasadnym, aby właśnie podczas badania przedprocesowego podjąć realną próbę pojednania małżonków.

W kontekście analizowanego postepowania prowadzonego przed procesem należy odnieść się do jego relacji względem dochodzenia wstępnego przed przyjęciem skargi powodowej. Na gruncie kanonistyki polskiej zwolennikiem prowadzenia dochodzenia wstępnego był ks. W. Padacz ${ }^{28}$. Takie dochodzenie występowało w wielu trybunałach kościelnych Ameryki Północnej oraz Niemiec ${ }^{29}$ jeszcze przed promulgacją Instrukcji procesowej „Dignitas connubii”. Inny kanonista R. Sobański był zdecydowanym przeciwnikiem prowadzenia takiego dochodzenia. Uważał, że skoro sędzia ma wątpliwości co do zasadności skargi, to w takim przypadku powinien zwrócić się do strony powodowej o uzupełnienie lub wyjaśnienie skargi ${ }^{30}$. Jednak prawodawca w art. 120 Instrukcji procesowej „Dignitas connubii” dał możliwość przeprowadzenia dochodzenia wstępnego przed przyjęciem skargi powodowej. To postępowanie różni się zasadniczo od tego, które zostało zaproponowane przez „Zasady proceduralne w sprawach o stwierdzenie nieważności małżeństwa”. Pierwsza różnica polega na tym, że dochodzenie wstępne następuje po złożeniu skargi powodowej, zaś badanie przedprocesowe jest prowadzone przed jej złożeniem. Dochodzenie wstępne bada kompetencje sądu, zdolność procesową powoda oraz istnienie podstaw do złożenia skargi. Natomiast badanie przedprocesowe ma szerszy zakres, ponieważ pomaga petentowi określić ewentualne podstawy nieważności małżeństwa, ale także zapewnia mu wsparcie duszpasterskie, o czym było już powyżej wspomniane. Kompetentnie procedowane badanie przedprocesowe w większości czyni zbytecznym prowadzenie dochodzenia wstępnego przed przyjęciem skargi.

\footnotetext{
28 Por. W. Padacz, Zagadnienie konieczności badania przedsądowego, Homo Dei 28 (1958), s. 55.

29 Por. R. CAmpisi, I motivi di reiezione del libello. Prassi dei Tribunali Ecclesiastici Regionali Italiani e giurisprudenza della Rota Romana, s. 53; R. SoBAŃsкi, Przyjęcie skargi o orzeczenie nieważności małżeństwa, Ius Matrimoniale 6-7 (1996) nr 1, s. 150. 30 Por. R. SobAński, Przyjęcie skargi o orzeczenie nieważności małżeństwa, dz. cyt., s. 151.
} 


\section{Kompetencje osób odpowiedzialnych za prowadzenia badania przedprocesowego}

Prawodawca kościelny w sposób lakoniczny określił przymioty osób, które można desygnować na prowadzących badanie przedporcesowe. Według „Zasad proceduralnych w sprawach o stwierdzenie nieważności małżeństwa" mają być to osoby kompetentne, nawet niekoniecznie prawno-kanonicznie. Brak nakazanej przez prawodawcę procedury badania przedprocesowego umożliwia ustanowienie odpowiedzialnymi osób bez wykształcenia kanonistycznego. Prawodawca na pierwszym miejscu stawia proboszcza lub osobę przygotowująca do zawarcia małżeństwa. Jest to związane z tym, że owe osoby powinny mieć lepsze rozeznanie co do okoliczności zawierania małżeństwa. $\mathrm{Z}$ tego względu mogą one w sposób bardziej pełny ocenić sytuacje, w których znalazły się osoby żyjące w separacji lub po rozpadzie małżeństwa. Poza tym to badanie ma wymiar duszpasterski. Zatem proboszcz jako duchowny może bezpośrednio i natychmiast otoczyć takie osoby swoją pomocą duszpasterską. Osobą odpowiedzialną lub zespołem osób odpowiedzialnych za przygotowanie do małżeństwa są zwykle duchowni i dlatego prawodawca wskazał ich na pierwszym miejscu jako osoby właściwe do prowadzenia badania i zapewnienia pomocy duszpasterskiej. Natomiast inne osoby, które współuczestniczyły w przygotowaniach do małżeństwa lub też mają odpowiednie predyspozycje zarówno duchowni, osoby konsekrowane jak też świeccy mogą się przyczynić do niesienia innych form pomocy, które są ściśle związane z duszpasterstwem. Przykładem takiego wsparcia może być pomoc psychologiczna, terapeutyczna czy też prawno-kanoniczna.

Według art. 3 „Zasad proceduralnych w sprawach o stwierdzenie nieważności małżeństwa”, osobami, którym można powierzyć zadanie prowadzenia dochodzenia mogą być duchowni, osoby życia konsekrowanego lub świeccy zatwierdzeni przez ordynariusza miejsca. Kompetencje tych osób nie mogą być pewne i dlatego każda z nich powinna mieć zatwierdzenie ordynariusza miejsca. P. Kroczek 
stwierdził, że formą zatwierdzenia może być nihil obstat, która jest prostsza i mniej autoryzująca niż mandatum czy missio canonica ${ }^{31}$.

Biorąc pod uwagę złożoność sytuacji osób, które doświadczyły rozpadu małżeństwa najbardziej rozsądnym rozwiązaniem jest powołanie zespołu osób, spośród których każda $\mathrm{z}$ nich może pomóc w konkretnym przypadku wykorzystując własne kompetencje. Osoby doświadczone dramatem rozbicia małżeństwa mogą mieć różne potrzeby i dlatego taki zespół powinien dysponować szerokim wachlarzem ofert. Niektórzy bardziej potrzebują pomocy duchowej i dlatego przydatny będzie duszpasterz, który poprowadzi rozmowę. W innym przypadku będzie bardziej potrzebna pomoc psychologa, bo osoba nie będzie potrafiła się odnaleźć w nowej sytuacji i podjąć dotychczasowych obowiązków. W szczególnych sytuacjach może być potrzebna pomoc terapeuty rodzinnego lub innego specjalisty. Ponadto może zdarzyć się sytuacja, że na badanie przedprocesowe zgłaszają się osoby, których małżeństwo można uratować i doprowadzić do pojednania. Wówczas zasadnym będzie przeprowadzenie rozmowy z osobą, która potrafi poprowadzić terapię pojednawczą lub też skierować do takiej instytucji, która udzieli stosownej pomocy. Natomiast pomoc kanonisty może się okazać konieczna w sytuacji, gdy nie ma szans na pojednanie stron i pojawiają się przesłanki wskazujące na to, że małżeństwo zostało zawarte w sposób nieważny.

\section{Formacja osób odpowiedzialnych za prowadzenie badania przedprocesowego}

Osoby, które zostaną wyznaczone do prowadzenia badania przedprocesowego lub też wchodzą w skład zespołu prowadzącego takie badanie powinny być poddane odpowiedniej formacji. Chociaż prawodawca nie wspomina o tym w sposób wyraźny, to jednak materia spraw, którymi mają się zajmować wymaga nieustannej formacji. Te osoby muszą mieć przede wszystkim światopogląd chrześcijański,

\footnotetext{
31 Por. P. Kroczek, Zasady proceduralne w sprawach o stwierdzenie nieważności małżéstwa, dz. cyt., s. 46.
} 
a formacja, którą będą objęci ma im tę kwestię przypominać i uświadamiać. Jej istotą powinno być kształtowanie sfery duchowej. Może to się odbywać na specjalne organizowanych dniach skupienia czy rekolekcjach. Osoby takie powinny korzystać z sakramentu pokuty i pojednania, Eucharystii, angażować się w sposób wszechstronny w życie religijne. Oprócz formacji duchowej takie osoby powinny doskonalić się w tych dziedzinach, które stanowią przedmiot pomocy w badaniu przedprocesowym. Warto byłoby dla takich osób organizować warsztaty, które pomogą w sposób właściwy ukierunkować ich wiedzę, aby jak najbardziej efektywnie wykorzystać to w badaniu duszpasterskim. Prawodawca kościelny zaproponował, aby diecezja albo kilka diecezji wspólnie ustanowiły strukturę i opracowały vademecum, aby jak najbardziej odpowiednio przeprowadzić badanie przedprocesowe ${ }^{32}$. W treści art. 3 „Zasad proceduralnych w sprawach o stwierdzenie nieważności małżeństwa" zostało powtórzone za art. 2, że diecezja ma stworzyć stałe struktury odpowiedzialne za prowadzenie dochodzenia przedprocesowego. Prawodawca jednak zasugerował, aby kilka diecezji w miarę możliwości przestrzennych podjęły współpracę w utworzeniu wspólnej struktury. Diecezje są tworzone w sposób trwały, zatem termin stała struktura nie odnosi się do instytucji danej diecezji ale do instytucji międzydiecezjalnej ${ }^{33}$. P. Kroczek podkreślił, że słowo diecezja należy rozumieć w znaczeniu szerokim i dlatego postanowienia prawodawcy odnoszą się do struktur zrównanych w prawie z diecezją czyli prałatury terytorialnej, opactwa terytorialnego, wikariatu apostolskiego, prefektury apostolskiej i administracji apostolskiej erygowanej na stałe ${ }^{34}$.

Wydaje się, że prawodawca celowo pozostawił pewną swobodę, aby biskupi diecezjalni mogli decyzję dotyczącą powołania struktur podjąć uwzględniając potrzeby i możliwości wynikające ze specyfiki

\footnotetext{
32 Por. Zasady proceduralne w sprawach o stwierdzenie nieważności małżeństwa, art. 3 .

33 Por. TAMżE.

34 Por. P. Kroczek, Zasady proceduralne w sprawach o stwierdzenie nieważności małżéstwa, dz. cyt., s. 46.
} 
terytorium, w skład którego wchodzą. Refleksja nad postanowieniami art. 3 „Zasad proceduralnych w sprawach o stwierdzenie nieważności małżeństwa”, prowadzi do wniosku, że jednak w każdej diecezji należy stworzyć taką strukturę. Kooperacja kilku diecezji może natomiast dotyczyć dwóch spraw i wydaje się najbardziej słusznym, aby miała ona miejsce na poziomie tej samej konferencji episkopatu.

Pierwszy postulat dotyczy tego, aby struktura odpowiedzialna za prowadzenie dochodzenia duszpasterskiego w każdej diecezji należącej do tej samej konferencji biskupów miała taki sam sposób organizacji. Taka jednolitość sprawi, że wierni którzy przynależą do różnych diecezji tej samej konferencji biskupów mogą wówczas liczyć na podobny sposób rozwiązywania sytuacji w których się znaleźli.

Drugi postulat odnosi się do vademecum, które może być pomocą w prowadzeniu takiej procedury. Byłoby wskazane, aby na terytorium tej samej konferencji biskupów istniały takie same reguły postępowania oraz takie same sposoby pomocy osobom doświadczonym rozpadem małżeństwa. Ścisła współpraca diecezji między sobą w opracowaniu organizacji struktur i vademecum postępowania może się przyczynić do wymiany doświadczeń, co w konsekwencji może prowadzić do doskonalenia i uzyskania optymalnych efektów badania duszpasterskiego.

P. Kroczek postulował, aby vademecum zawierało informacje dotyczące zagadnień prawnomaterialnych oraz proceduralnych badania przedprocesowego, a także podstawowych informacji z zakresu procesu o stwierdzenie nieważności małżeństwa ${ }^{35}$. Autor podkreślił, że pominięcie procedury, która zostanie wskazana w promulgowanym dokumencie nie powoduje nieważności zebranego materiału ${ }^{36}$. Wydaje się, że oprócz informacji dotyczących zagadnień z zakresu kanonistyki, należałoby zaoferować propozycję dla tych, którzy potrzebują innych form pomocy. Część tych osób może uzyskać wsparcie w duszpasterstwie rodzin, ale mogą zdarzyć się sytuacje, które wymagają stworzenia nowej oferty ze strony Kościoła.

\footnotetext{
35 Por. TAmże, s. 47.

36 Por. TAmżE.
} 


\section{Gromadzenie materiału dowodowego do celów procesowych}

Prawodawca w art. 4 ,Zasad proceduralnych w sprawach o stwierdzenie nieważności małżeństwa”, postanowił, że podczas badania przedprocesowego należy zebrać przydatne informacje dla ewentualnego wszczęcia sprawy przed właściwym trybunałem ${ }^{37}$. Z treści artykułu wynika klarownie, że chociaż ta procedura ma wymiar duszpasterski to jednak nie można pominąć aspektów typowo prawnych. Osoby odpowiedzialne za prowadzenie tego badania, oprócz opieki duchowej, mają również na tym etapie zebrać materiały, które posłużą jako dowody w procesie o stwierdzenie nieważności małżeństwa. Takimi informacjami mogą być różne dokumenty, którymi dysponują osoby. Osoby prowadzące mogłyby za zgodą petentów sporządzać notatki, które zawierałyby istotne informacje na temat różnych okoliczności związanych z małżeństwem, które się rozpadło. Taki zapis mógłby być pomocny w prowadzonym procesie wówczas, gdy strony nie są w stanie odtworzyć z pamięci różnych istotnych faktów.

Prawodawca w art. 4 „Zasad proceduralnych w sprawach o stwierdzenie nieważności małżeństwa”, zobowiązał prowadzących badanie przedprocesowe do tego, aby ustaliły czy strony są zgodne ze sobą w kwestii żądania stwierdzenia nieważności małżeństwa ${ }^{38}$. Wskazane zadanie jest ważne dla późniejszego postępowania, bo pomaga określić jaki typ procesu należy zastosować oraz określić podstawy prawne ewentualnej nieważności małżeństwa. Jest to szczególnie istotne w sytuacji, gdy pojawiają się przesłanki do prowadzenia procesu skróconego przed biskupem. Zgodnie z kan. 1683 KPK taki proces może być prowadzony tylko wtedy, gdy żądanie zostało zgłoszone przez obydwoje małżonków lub też przez jednego z nich za zgodą drugiego oraz materiał dowodowy wskazuje na ewidentną nieważność małżeństwa. M. Greszata-Telusiewicz uważa, że termin określający

\footnotetext{
37 Por. Zasady proceduralne w sprawach o stwierdzenie nieważności matżeństwa, art. 4 .

38 Por. TAMżE.
} 
zgodność małżonków należy rozumieć w sposób maksymalistyczny ${ }^{39}$. Nie jest zatem wystarczającym zgodność co do orzekania nieważności małżeństwa, ale jest koniecznym to, aby strony pozostały w pełnej dyspozycji dla sądu w dochodzeniu do prawdy obiektywnej oraz były zgodne co do tytułu nieważności małżeństwa ${ }^{40}$. Z wyżej wymienionych powodów na tym etapie badania duszpasterskiego jest najbardziej zasadnym, aby postępowanie prowadziła osobą będąca kanonistą albo przynajmniej była osobą biegłą w dziedzinie prawa kanonicznego.

Zebranie przydatnych informacji do wszczęcia procesu przed trybunałem kościelnym powinno zakończyć się sporządzeniem skargi o stwierdzenie nieważności małżeństwa ${ }^{41}$. Postanowienie prawodawcy należy interpretować w sposób szerszy. Osobie doświadczonej rozpadem małżeństwa należy udzielić wszelkich informacji dotyczących złożenia skargi. Podmiot odpowiedzialny za tę część procesu duszpasterskiego powinien wskazać trybunały właściwe do złożenia skargi oraz określić tytuły nieważności, które mogłyby być rozpatrywane w procesie. Osoby doświadczone rozpadem małżeństwa powinny zostać poinformowane, że mogą skorzystać z pomocy patrona, którym może być adwokat lub pełnomocnik ${ }^{42}$. W niektórych sytuacjach należy zaproponować, aby strony poprosiły o proces skrócony lub skorzystały z procedury dyspensy od małżeństwa niedopełnionego. Przedstawienie petentom różnych wariantów rozwiązań i pomoc w ich optymalnym wyborze wymaga od prowadzącego wiedzy kanonistycznej. Ponadto powinno się udzielić pomocy w sporządzeniu samej skargi powodowej. Z tego względu na tym etapie procedury najbardziej zasadnym jest powierzenie tego zadania kanoniście lub osobie biegłej w prawie kanonicznym.

39 Por. M. Greszata-Telusiewicz, Processus brevior, w: J. KrajCzyński (red.), Proces mał̇̇eński według motu proprio, dz. cyt., s. 83.

40 Por. TAmżE.

41 Por. Zasady proceduralne w sprawach o stwierdzenie nieważności małżeństwa, art. 4.

42 Por. P. KRoczer, Zasady proceduralne w sprawach o stwierdzenie nieważności małżéstwa, dz. cyt., s. 48. 
W przypadku braku osób kompetentnych w tej dziedzinie, należy skierować takich petentów do adwokata kościelnego lub też poradni, która działa przy trybunale kościelnym. Wówczas spełnienie zadania ostatniego etapu dochodzenia duszpasterskiego zostaje przeniesione na inny podmiot. Prawodawca przewidział, aby to w procedurze przedprocesowej umiejscowić gromadzenie materiału dowodowego oraz sporządzenie skargi powodowej, dlatego scedowanie tego zadania na inny podmiot nie powinno być zasadą, ale mieć miejsce tylko w szczególnie uzasadnionym przypadku. Celem takiej normy jest to, aby osoba doświadczona rozpadem małżeństwa nie musiała szukać ponownie rozwiązania swojej sytuacji życiowej. W ten sposób może ona oszczędzić czas na poszukiwanie pomocy oraz nie musi po raz kolejny przedstawiać swojej sytuacji życiowej kolejnej osobie, co niejednokrotnie wymaga wysiłku emocjonalnego i psychicznego. Ponadto taki petent zaoszczędzi koszty, które musiałby przeznaczyć na honorarium dla adwokata.

\section{Zakończenie}

Badanie przedprocesowe czyli duszpasterskie jest nową instytucją prawną, która powstała na mocy nowelizacji KPK. Stanowi ona odpowiedź na wyzwania dotyczące problemów osób znajdujących się po rozpadzie związku małżeńskiego zawartego w Kościele. Ta procedura ma poprawić dostępność osób do informacji na temat swojej aktualnej sytuacji kanonicznej w Kościele, a także pomóc w tym, aby w uzasadnionym przypadku uregulować ją zgodnie z przepisami prawa kanonicznego. Ma temu służyć powołanie specjalnych struktur i osób odpowiedzialnych do tego, aby pomagały określić możliwość i podstawy prowadzenia procesu o stwierdzenie nieważność małżeństwa. Osobom doświadczonym rozpadem małżeństwa należy jednak przypominać w czasach coraz bardziej powszechnej nietrwałości i mentalności rozwodowej, że proces o stwierdzenie nieważności małżeństwa jest postępowaniem wyjątkowym we wspólnocie Kościoła, który jest 
zobowiązany bronić trwałości małżeństwa ${ }^{43}$. Należy mieć na uwadze, że nie wszystkie sytuacje osób, które poproszą o badanie przedprocesowe będą się kwalifikowały do rozpoczęcia procesu o stwierdzenie nieważności małżeństwa. Wówczas osoby odpowiedzialne za prowadzenie badania przedprocesowego powinny zaproponować takie rozwiązanie duszpasterskie, które pomoże takim wiernym odnaleźć swoje miejsce we wspólnocie Kościoła.

\section{The pre-judicial or the pastoral inquiry in the light of the motu proprio "Mitis Iudex Dominus Iesus"}

\section{Summary}

The amendment to the process to declare the nullity of marriage introduced a new institution, a pre-judicial or a pastoral inquiry. The purpose of this procedure is to help those who have experienced the drama of breaking up a sacramental marriage. The diocesan bishop and the parish priest are responsible for helping such persons. An inquiry should be entrusted to other persons who will be adequately prepared for this.

A pre-judicial inquiry is intended to be a tool to help assess the situation of such persons in order to determine the legitimacy case to present petition to the competent tribunal. Faithfull in the pastoral inquiry should be acquainted with the procedure and should help them to prepare formally to start process to declare the nullity of marriage. Some situations do not qualify for declaring the nullity of marriage. Then the pastoral inquiry should help those who have experienced the breakup of marriage to point out other forms of help that will service them to find the role, the meaning, and the function in the community of the Church.

For this reason, the ecclesiastical law obliged those responsible for carrying out this procedure to cooperate with other legal entity who have the possibility to provide adequate assistance within the framework of structures of pastoral care of marriage.

${ }^{43}$ Por. T. Rozkrut, Wprowadzenie i instrukcja sprawy, w: Praktyczny komentarz do Listu apostolskiego motu proprio „Mitis Iudex Dominus Iesus” papieża Franciszka, (red.) P. SKonieczny, Tarnów 2015, 42. 